\title{
Mini-Projects in Chemical Engineering Laboratory
}

\author{
http://dx.doi.org/10.3991/ijep.v3iS2.2453 \\ A. Cancela ${ }^{1}$, A. Sanchez ${ }^{1}$ and R. Maceiras ${ }^{2}$ \\ ${ }^{1}$ University of Vigo, Vigo, Spain \\ ${ }^{2}$ Defense University Center, Marin
}

\begin{abstract}
Chemical engineering laboratory practices based in mini-projects were design and applied the students of forestry engineering in chemical subject. This way of practice reveals a more cooperative learning and a different style of experimentation. The stated goal was to design practices that motivate students and to enable them to develop different skills, including cross teamwork and communication. This paper describes how these practices were developed and the advantages and disadvantages of using this methodology of teaching.
\end{abstract}

Index Terms-laboratory practices, mini-projects, cooperative learning, rubric.

\section{INTRODUCTION}

In the last decade, the engineering profession requires different personal skills and technical competencies and professional skills. Engineers require breadth in their education to understand and engage with the broader problems facing society. They must not only solve problems of society, but also should contribute to the debate, for that they must ask the right questions about how we should develop as a society in the future. The engineers are undergone to the continuous technological change, and they should try to incorporate into their knowledge base and their personal skills to the change professional practices For these reasons the engineering education and industry have request the assistance of educators to provide engineers with these skills [1].

In response to the changing expectations of the engineers, technical and personal skills required by engineers in the industry had been to determine. In different studies have indicated that engineering graduates need to have teamwork skills and communication skills [2].

Teams of engineering educators have been working to incorporate different communication skills with speaking and writing in engineering education [3]. Communication skills are essential for an engineer who aspires to carry out his professional practice in the global area. Engineering communication skills basically constitute several core elements [4]. Engineering practice takes place in an intensely oral culture and while formal presentations are important to practicing engineers, daily work is characterized more by interpersonal and small group experiences. Communication skills such as translation, clarity, negotiation, and listening are vital.

Professional development is becoming increasingly important, although it is not a new concept. The continuing pace of change in engineering means that what we learned in our initial training courses soon becomes dated and irrelevant. It has been estimated that the half-life of technical knowledge is about seven years. Furthermore, the amount of knowledge -and the amount of informationcontinues to increase. Engineering has become knowledge intensive: we have entered the knowledge-based economy [5]. Nowadays it is impossible for us to know all that there is to know; yet access to the knowledge base is increasingly readily available. So what will make us good technologists is that our knowledge is more relevant, and more current, and is applied more efficiently and effectively.

The framework has changed. Today engineers are expected to have many skills (see Table I). Increasingly the team work is developed in order to make a success of the projects, the work is often done with mixed virtual and face part. It changes its design, equipment and workplace. When a project ends, another begins, and so on.

The skill set required for contemporary engineering practice is changing rapidly and will continue to do so even more in the years ahead [6]. Beyond a strong foundation in fundamentals such as science, mathematics, and engineering sciences, engineers require broader skills such as those suggested (see Table II).

It has been said that engineering is the engine of innovation. If so, then science is its fuel. As Bordogna ob-

TABLE I.

THE SKILLS REQUIRED BY PROFESSIONAL ENGINEERS [5]

\begin{tabular}{|c|}
\hline Skills \\
\hline Apply knowledge of contemporary and cultural issues. \\
\hline Apply knowledge of mathematics, science and engineering. \\
\hline Appreciate the impact of engineering solutions in the global and \\
social context. \\
\hline Communicate effectively. \\
\hline Design a system, component or process to meet specified needs. \\
\hline Design and conduct experiments, and analyse and interpret data. \\
\hline Formulate and solve engineering problems. \\
\hline Function in multidisciplinary teams. \\
\hline Information technology and management skills. \\
\hline $\begin{array}{c}\text { Interpret and employ guidelines on professional and ethical respon- } \\
\text { sibility. }\end{array}$ \\
\hline $\begin{array}{c}\text { Use the technical skills and engineering tools necessary for modern } \\
\text { engineering practice. }\end{array}$ \\
\hline Work in teams or in collaboration with others. \\
\hline
\end{tabular}


TABLE II.

THE SKILLS SUGGESTED BY ENGINEERS [7]

\begin{tabular}{|c|}
\hline Skills \\
\hline Engineering science (analysis). \\
\hline Systems integration (synthesis). \\
\hline Problem formulation as well as problem solving. \\
\hline Engineering design. \\
\hline The ability to realize products \\
\hline Facility with intelligent technology to enhance creative opportunity \\
\hline Ability to manage complexity and uncertainty \\
\hline Teamwork (sensitivity in interpersonal relation-ships) \\
\hline Language and multicultural understanding \\
\hline Ability to advocate and influence \\
\hline Entrepreneurship and decision making \\
\hline Knowledge integration, education, and mentoring \\
\hline
\end{tabular}

serves [7], "Engineers stand at the fulcrum of scientific and technological change, creating new knowledge, artifacts and systems; stimulating economic development; creating wealth and jobs; sharpening the nation's competitive edge; raising our prospects for more productive and satisfying lives; caring for the environment; and strengthening our national security." He goes on to conclude that engineering education is at the very heart of these issues. Demands are increasing for a holistic breed of engineersgraduates with the skill to work across intellectual, social, and cultural boundaries.

It is necessary to make changes in the current education system to ensure that engineering students acquire different skills, such as the application of critical thinking. Students have a good knowledge of engineering, but do not know how to apply in practice. Also should have a global perspective of social, environmental and economic issues related to their profession.

Critical thinking and other similar skills can only be achieved through cooperative learning in the classroom. The degree of development of these skills determines how teamwork, problem solving, and writing reports, and selfassess and make performance evaluations ... [8].

The process skills are important for many teachers, but it is difficult to promote the development of skills in students. The skills related to attitudes and values are difficult to define explicitly, to develop and evaluate. Research suggests that the development of any skill is associated to practice. The teacher's role is primarily that of a coach, encouraging students to achieve the objectives attitudes and skills and provide feedback on their efforts.

In the curriculum of the various engineering, there are many matters that have a significant number of credits for practices, with few credits allocated to the lectures. The use of a teaching method for the laboratory to ensure the acquisition of skills is essential to complete the overall teaching of a subject with the experimental For this reason, it is necessary to employ the laboratory activities in many science disciplines to promote the acquisition of certain skills. A subject of this type is the chemical.
In recent decades, the teaching of chemistry in the laboratory has been repeatedly discussed. There are different types of laboratory-based teaching. All are based on the expected outcome of the lab session, the student's approach and method is provided.

Currently, the most commonly used in the laboratory class is recipe-style. Though studies have concluded that this technique is not good. Students are not involved in the broader purpose of the investigation, they work sequentially to complete the task, but they do not stop to think about what you are doing at any time. [9].

In our university, the forester curriculum meets the standard of engineering curriculum. Many subjects have practices and a few hours to give all the theoretical part. Therefore, the way is to acquire some skills, including cross skills, it is developing the practice in a way that students are not only acquired matter specific skills.

In this work, we design the laboratory practices of chemical engineering as mini-projects. We are trying to give them the focus of the learning company approach to lead classroom practice to a more cooperative learning and a different style of experimentation. A chemistry lesson's lab-work towards self-regulated learning was opening up and that it leads to a different learning atmosphere. The described lesson plan leads towards a different style of lab-work, which promotes more student activity and involvement in the process of experimentation. So we want to achieve chemistry specific skills, teamwork skills, decision-making and other skills necessary for professional development.

In this paper, we present the development of practices of chemistry; it is a signature of first-year of forestry. The used methodology was the mini-projects instead of traditional method "recipe-style".

\section{SUBJECT IN SCHOOL OF FORESTRY}

The Chemistry in the School of Forestry at the University of Vigo is a subject of the first course. The students have different profiles; some students come from Bachelor of Professional Studies and others come from high school. The content of subject is divide seven themes.

1. Basic concepts: atoms, periodic table, molecules, mixtures...

2. Atomic structure and chemical bonding.

3. Energy, gas chemistry equilibrium and solubility.

4. Gases, liquids, solids and solutions.

5. Acid-base reactions

6. Oxidation-reduction reactions.

7. Organic chemistry.

The used teaching methodology is divided in face-toface and non-face classes. Face classes include lectures, seminars and laboratory sessions. And no face classes are performed in groups of three students, who have to solve and deliver, on the indicated date, the proposed exercises for each of the classroom topics.

The evaluation of the subject is divided into three parts, lectures and seminars (50\%), laboratory (30\%), and working groups (20\%). The student must reach at least a $50 \%$ of the maximum provided for each activity to pass the subject. The assessment of lectures and seminars is madding for written examination of the contents of the subject on the official date. The laboratory assessment is made 
using a rubric, and the working groups assessment is based on submitted exercises.

As it can be seen in the subject distribution, laboratory practices are an important part of the subject. For this reason, it is very important proposed miniprojects that involves all parts of subject.

\section{DISTRIBUCCION OF MinipROJECTS}

In order to cover the more general fields of basic chemical engineers, laboratory work was divided into different mini-projects (see table III). They were developed over practice sessions.

In initial practice sessions, students remember the use of common laboratory equipment, and reinforce the essential concepts of chemistry, and later in other sessions, they develop small-scale industrial projects, as miniprojects.

In each miniproject, it intends that students acquire different skills, generic (knowledge about chemistry laboratory), specific (ability to understand and apply the basic principles of chemistry to the miniproject) and transferable (oral and written in the native language, learning and teamwork). These skills are necessary for professional development and they are acquired in other subjects. One example of miniproject about third theme of theory can be seen in a table IV.

Three of the five proposed miniprojects have to be made by each group of students. In each group there are three students. The groups must comprise a thorough mix of high achieving and no so high achieving learners. Each group establishes the roles of each student before the activity since it is necessary to choose the author of the report and the student who makes the oral presentation. To assign the roles, the students have to be in account the abilities of each student. The three member of the group make the experimental part.

For carrying out the miniproject, the students have to do a job plannig which is developed with the theoretical information and their own ideas. To elaborate the planning job the students have to be in account the materials and equipment available in the laboratory. With this information, they have to find possible strategies for developing the miniproject. The aim of this activity is that the students learn basic concepts of chemistry, materials and reactive, used experimentation techniques.

The activity is carry out in fifteen weeks with sessions of two hours per week. Before doing the miniprojects, the teacher uses two laboratory sessions to students know the basic techniques of chemistry and the available equipment since the learning about the function of the lab equipment and materials is essential for any subject of the first course. During these sessions, the teacher offers information about the basic and separation techniques (titration, distillation), solution preparation. These activities represent the first stage of the learning process (figure 1).

In the third laboratory session, the groups begin to do the miniprojects. First of all, they choose the one of the total. The miniproject is divided in different steps that include the following aspects (figure 2): selection miniproject of list; literature review, selection of experimental technique; work plan; laboratory experiences; calculation of results; report and oral presentation. In this lab session, the groups began with the literature review and the selection of the experimental technique. After that, the teacher
TABLE III.

LIST OF MINIPROJECTS

\begin{tabular}{|c|c|c|}
\hline \multirow{2}{*}{$\mathbf{N}}$. & Themes and concepts of miniprojects \\
\cline { 2 - 3 } & Themes & Concepts \\
\hline 1. & Calorimetry & $\begin{array}{c}\text { Measurement of enthalpies } \\
\text { of reaction }\end{array}$ \\
\hline 2. & Chemical Equilibrium & Le Chatelier's principle \\
\hline 3. & Chemical Kinetics & $\begin{array}{c}\text { Effect of the concentration } \\
\text { and temperature. }\end{array}$ \\
\hline 4. & Volumetric acid-base & Titration curve \\
\hline 5. & Electrochemical processes & Electrolyses \\
\hline
\end{tabular}

TABLE IV.

EXAMPLE OF MINIPROJECTS

\begin{tabular}{|c|c|}
\hline \multicolumn{2}{|l|}{ Description } \\
\hline Problem & Task \\
\hline $\begin{array}{l}\text { The manager of a company need employed an } \\
\text { excess of } 10 \text { tons of } \mathrm{NaOH} \text { that it is obtained in } \\
\text { the process of production so subproduct. Due to } \\
\text { the fact that the price of diesel is increased con- } \\
\text { tinuously, he asked to a chemistry of his company } \\
\text { to study the viability. This study would consist of } \\
\text { using the generated heat by mixing water and } \\
\text { NaOH in a tank of } 50 \mathrm{~L} \text { volume to heat the water } \\
\text { of heating office. }\end{array}$ & $\begin{array}{l}\text { Submit a } \\
\text { report of the } \\
\text { feasibility } \\
\text { study }\end{array}$ \\
\hline
\end{tabular}

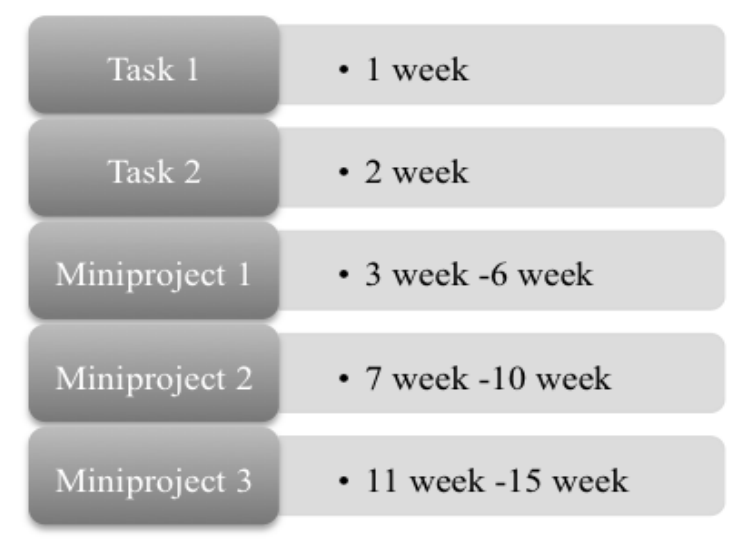

Figure 1. Task-time.

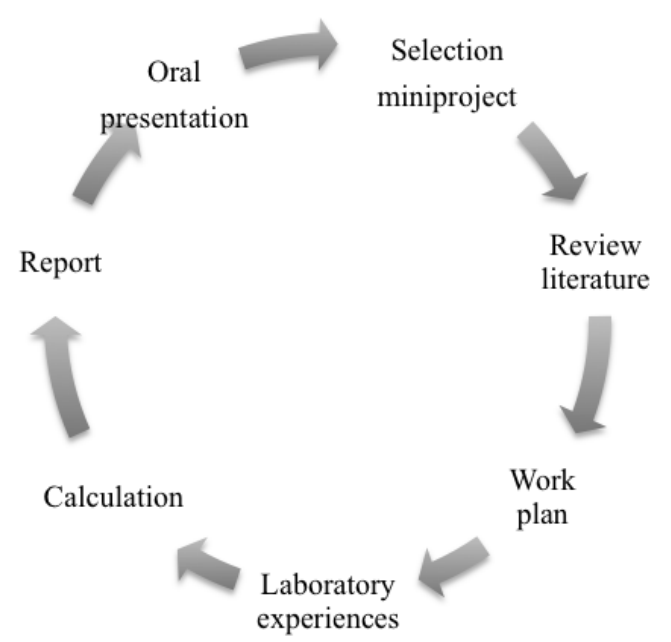

Figure 2. Flowchart of a miniproject

revises the information of each group about the objectives of their miniproject and the proposed techniques to solve it. Once this information is analyzed, the teacher asked them to choose one experimental technique and perform the work plan. 
In the fourth session, the group members began to work, and prepare the work plan and explain it to the teacher. The planning of the experiment, the materials and necessary equipment should be discussed with the teacher before beginning the practical activity. If the students need help they can use textbooks. In the case that one group cannot make the plan, the teacher help to students giving some ideas or even giving a solution, since the objective of the sessions is that the students learn the techniques and therefore they must do the experiments. The fifth week, each group of students carry out their experimental work obtains the data and make the calculations. After the lab session, they prepare the report and the oral presentation out of the class. The sixth week, all the groups present their activity for the whole class and submit the report to the teacher.

\section{EVALUATION}

The evaluation of the miniprojects is in groups and each group competes with the other groups in the elaboration of the report and presentation.

The miniproject is evaluated using a rubric. This rubric analyzes different aspects related to the development of miniproject, laboratory work, the presentation of the report and the students' attitude. This rubric is used with all groups since laboratory work is mandatory for all students. The final evaluation of each student is carried out taking into account two items: the degree of interest shown in the laboratory work by the student and the obtained qualification in the rubric by the group. The items of rubric are: materials, procedures, calculations, data (tables, graphs), replicability, conclusion, participation, safety, appearance and organization (table V).

TABLE V.

RUBRIC OF MINIPROJECT

\begin{tabular}{|c|c|c|c|c|}
\hline & \multicolumn{4}{|c|}{ Points } \\
\hline & 2 & 1 & 0.5 & $\mathbf{0}$ \\
\hline \multicolumn{5}{|c|}{ Laboratory and report } \\
\hline Materials & $\begin{array}{l}\text { All materials used in the } \\
\text { experiment are clearly } \\
\text { and accurately described. }\end{array}$ & $\begin{array}{l}\text { Almost all materials used in } \\
\text { the experiment are clearly } \\
\text { and accurately described. }\end{array}$ & $\begin{array}{l}\text { Most of the materials used in } \\
\text { the experiment are accurately } \\
\text { described. }\end{array}$ & $\begin{array}{l}\text { Many materials are } \\
\text { described inaccurately or } \\
\text { are not described at all. }\end{array}$ \\
\hline Procedures & $\begin{array}{l}\text { They are listed in clear } \\
\text { steps. Each step is } \\
\text { numbered and is a } \\
\text { complete sentence. }\end{array}$ & $\begin{array}{l}\text { They are listed in a logical } \\
\text { order, but steps are not } \\
\text { numbered and/or are not in } \\
\text { complete sentences. }\end{array}$ & $\begin{array}{l}\text { They are listed but are not in } \\
\text { a logical order or are difficult } \\
\text { to follow. }\end{array}$ & $\begin{array}{l}\text { They do not accurately } \\
\text { list the steps of the } \\
\text { experiment. }\end{array}$ \\
\hline Calculations & $\begin{array}{l}\text { All calculations are } \\
\text { shown and the results are } \\
\text { correct and labeled } \\
\text { appropriately. }\end{array}$ & $\begin{array}{l}\text { Some calculations are shown } \\
\text { and the results are correct } \\
\text { and labeled appropriately. }\end{array}$ & $\begin{array}{l}\text { Some calculations are shown } \\
\text { and the results labeled } \\
\text { appropriately. }\end{array}$ & $\begin{array}{l}\text { No calculations are } \\
\text { shown OR results are } \\
\text { inaccurate or mislabeled. }\end{array}$ \\
\hline Data & $\begin{array}{l}\text { Professional looking and } \\
\text { accurate representation of } \\
\text { the data in tables and/or } \\
\text { graphs. Graphs and tables } \\
\text { are labeled and titled. }\end{array}$ & $\begin{array}{l}\text { Accurate representation of } \\
\text { the data in tables and/or } \\
\text { graphs. Graphs and tables are } \\
\text { labeled and titled. }\end{array}$ & $\begin{array}{l}\text { Accurate representation of } \\
\text { the data in written form, but } \\
\text { no graphs or tables are } \\
\text { presented. }\end{array}$ & $\begin{array}{l}\text { Data are not shown or are } \\
\text { inaccurate. }\end{array}$ \\
\hline Conclusion & $\begin{array}{l}\text { Conclusion includes } \\
\text { whether the findings } \\
\text { supported the hypothesis, } \\
\text { possible sources of error, } \\
\text { and what was learned } \\
\text { from the experiment. }\end{array}$ & $\begin{array}{l}\text { Conclusion includes whether } \\
\text { the findings supported the } \\
\text { hypothesis and what was } \\
\text { learned from the experiment. }\end{array}$ & $\begin{array}{l}\text { Conclusion includes what } \\
\text { was learned from the } \\
\text { experiment. }\end{array}$ & $\begin{array}{l}\text { No conclusion was } \\
\text { included in the report or } \\
\text { shows little effort and } \\
\text { reflection. }\end{array}$ \\
\hline \multicolumn{5}{|c|}{ Laboratory work } \\
\hline Participation & $\begin{array}{l}\text { Used time well in lab and } \\
\text { focused attention on the } \\
\text { experiment. }\end{array}$ & $\begin{array}{l}\text { Used time pretty well. Stayed } \\
\text { focused on the experiment } \\
\text { most of the time. }\end{array}$ & \begin{tabular}{|l|} 
Did the lab but did not appear \\
very interested. Focus was \\
lost on several occasions.
\end{tabular} & \begin{tabular}{|l|} 
Participation was \\
minimal or student was \\
hostile about \\
participating. \\
\end{tabular} \\
\hline Safety & $\begin{array}{l}\text { Lab is carried out with } \\
\text { full attention to relevant } \\
\text { safety procedures. The } \\
\text { set-up, experiment, and } \\
\text { tear-down posed no } \\
\text { safety threat to any } \\
\text { individual. }\end{array}$ & $\begin{array}{l}\text { Lab is generally carried out } \\
\text { with attention to relevant } \\
\text { safety procedures. The set- } \\
\text { up, experiment, and tear- } \\
\text { down posed no safety threat } \\
\text { to any individual, but one } \\
\text { safety procedure needs to be } \\
\text { reviewed. }\end{array}$ & $\begin{array}{l}\text { Lab is carried out with some } \\
\text { attention to relevant safety } \\
\text { procedures. The set-up, } \\
\text { experiment, and tear-down } \\
\text { posed no safety threat to any } \\
\text { individual, but several safety } \\
\text { procedures need to be } \\
\text { reviewed. }\end{array}$ & $\begin{array}{l}\text { Safety procedures were } \\
\text { ignored and/or some } \\
\text { aspect of the experiment } \\
\text { posed a threat to the } \\
\text { safety of the student or } \\
\text { others. }\end{array}$ \\
\hline \multicolumn{5}{|c|}{ Report and oral presentation } \\
\hline Appearance / Organization & \begin{tabular}{|l} 
It is typed and uses \\
headings and \\
subheadings to visually \\
organize the material.
\end{tabular} & $\begin{array}{l}\text { It is neatly handwritten and } \\
\text { uses headings and } \\
\text { subheadings to visually } \\
\text { organize the material. }\end{array}$ & $\begin{array}{l}\text { It is neatly written or typed, } \\
\text { but formatting does not help } \\
\text { visually organize the } \\
\text { material. }\end{array}$ & $\begin{array}{l}\text { It is handwritten and } \\
\text { looks sloppy with cross- } \\
\text { outs, multiple erasures } \\
\text { and/or tears and creases. }\end{array}$ \\
\hline Oral presentation & $\begin{array}{l}\text { Presentation of infor- } \\
\text { mation to class was } \\
\text { organized, understan- } \\
\text { dable, and accurate. }\end{array}$ & $\begin{array}{l}\text { Presentation of information } \\
\text { to class was mostly } \\
\text { organized, understandable, } \\
\text { and accurate. }\end{array}$ & $\begin{array}{l}\text { Presentation of information } \\
\text { to class was somewhat } \\
\text { organized, understandable, } \\
\text { and accurate. }\end{array}$ & $\begin{array}{l}\text { Presentation of infor- } \\
\text { mation to class was not } \\
\text { organized, understan- } \\
\text { dable, and accurate. }\end{array}$ \\
\hline
\end{tabular}




\section{Activity Evaluation}

At the end of the activity, one questionnaire of three questions is filled by the students with the objective of knowing the students' opinion about the miniprojects compared to the traditional laboratory sessions. The obtained results indicated that the $70 \%$ of students prefer the use of miniprojects while a $27 \%$ of the students do not matter any method, and only a $3 \%$ of the students prefer the traditional method.

\section{CONCLUSIONS}

The results of other authors support the idea that the opening of a chemistry lab lesson work towards selfregulated learning is possible, leading to a different learning environment. Nowadays, the way of teaching is changing for a different style of laboratory work, with the idea that student participate more actively, the student not only is limited to follow the recipe but also has to think about to do it and carry out it. This type of activity is well received by students, due to its the possibility of finding oneself methods and follow their own ideas in the performance of laboratory tasks. Moreover, the use of these methods allow to the students acquire different skills necessary to professional development (generic, specific and transferable). Nevertheless, the teacher must be a great effort to develop this type of activity, since the teacher have to be on the site of the student, and apart from the information that the student has, he must develop miniproject with the help of reference material and supported by information provided by the teacher (himself).

\section{REFERENCES}

[1] A. Rugarcia, R. M. Felder, D. R. Woods, J. E. Stice. "The Future of Engineering Education. I. A Vision for a New Century”. Chem. Engr. Education, Vol. 34, Nº1, pp. 16-25, 2000.
[2] L. Shuman, M. Besterfield-Sacre, J. Mcgourty “The ABET Professional Skills- Can They Be Taught? Can They Be Assessed?” J. Eng. Educ., Vol. 41, pp. 41-55, 2005.

[3] A. L. Darling and D. P. Dannels. "Practicing Engineers Talk about the Importance of Talk: A Report on the Role of Oral Communication in the Workplace”. Commun. Educ., Vol. 52, pp. 1-16, 2003. http://dx.doi.org/10.1080/03634520302457

[4] Marc J. Riemer. "English and Communication Skills for the Global Engineer”. Global J. of Eng. Educ., Vol. 6, Nº1, pp. 91100, 2002.

[5] . J. Wilcox. Developing Professional Skills. The. UK Centre for Materials Education, 2003.

[6] J. Bordogna, "Round, Flat, or Spiky: The World Turns on an Axis”, IEEE-USA Leadership Workshop. Washington: IEEE, 2006.

[7] J. J. Duderstadt. "Engineering for a Changing World". The Millennium Project, The University of Michigan, 2008.

[8] D.R.Woods, R.M. Felder, A. Rugarcia, J.E. Stice "The future of engineering education III. Developing critical skills”. Chem. Eng. Educ., vol. 34, pp. 108-117, 2000.

[9] A. Hofstein and V.N. Lunetta. "The laboratory in science education: foundations for the twenty-first century”. Sci. Educ., vol. 88, pp. 28-54, 2004. http://dx.doi.org/10.1002/sce.10106

\section{AUTHORS}

A. Cancela is assistant professor of the Chemical Engineering Department at the University of Vigo, Ph.D. on Chemical Engineering (e-mail: chiqui@uvigo.es).

A. Sánchez is professor of the Chemical Engineering Department at the University of Vigo, Ph.D. on Chemical Engineering (e-mail: asanchez@uvigo.es).

R. Maceiras is doctor professor of the Defense University Center at the Naval Academy, attached to the University of Vigo. In Marín, Spain. Ph.D. on Chemical Engineering. (e-mail: rmaceiras@uvigo.es).

This article is an extended and modified version of a paper presented at the International Conference on Engineering Pedagogy (IGIP2012), held 26 - 28 September 2012, in Villach, Austria. Received 17 December 2012. Published as resubmitted by the authors 27 February 2013. 